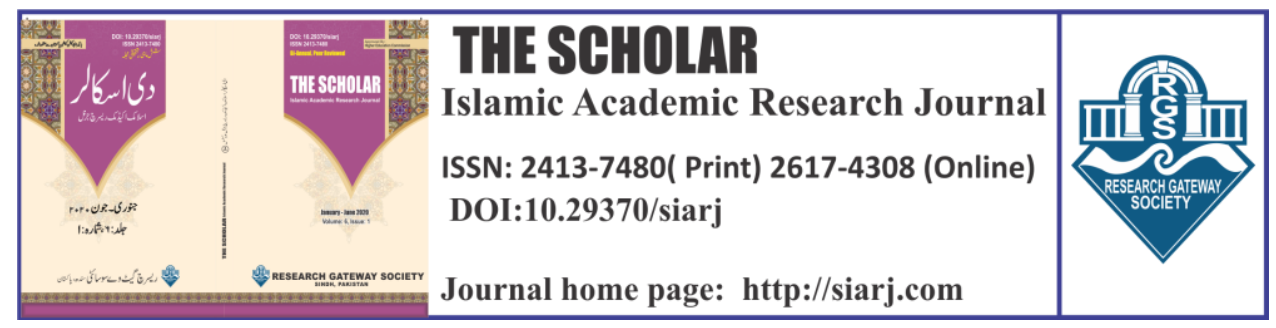

\title{
COVID-19: ITS IMPACTS AND MANAGEMENT IN THE ISLAMIC SOCIETY OF PAKISTAN
}

\section{Sayeda Daud}

Dean of Social Sciences and

Humanities, Greenwich University,

Karachi.

Email: sayedadaud@gmail.com

ORCIID IID:

https://orcid.org/0000-0002-6867-8489

\section{Masroor Khanum}

Assistant Professor, Federal Urdu

University, Karachi

Email:masroor.khanum@fuuast.edu.pk

ORCIID IID:

https://orcid.org/0000-0002-3845-8899

\section{Fatima Agha Shah}

Director Academics, Focus Institute of IT and Management Sciences, Karachi Email: dr.fatimaagha@gmail.com

\section{ORCID ID: https://orcid.org/0000-0002-0641-6707}

To cite this article:

Daud, Sayeda, Masroor Khanum, and Fatima Agha Shah. "ENGCOVID-19: ITS IMPACTS AND MANAGEMENT IN THE ISLAMIC SOCIETY OF PAKISTAN." The Scholar-Islamic Academic Research Journal 6, No. 1 (May 31, 2020): 335-378.

To link to this article: https://doi.org/10.29370/siari/issue10aren22

\begin{tabular}{|c|c|}
\hline Publisher & $\begin{array}{l}\text { The Scholar Islamic Academic Research Journal } \\
\text { Vol. 6, No. } 1 \text { || January -June } 2020 \text { || P. 353-378 } \\
\text { Research Gateway Society }\end{array}$ \\
\hline DOI: & $10.29370 /$ siarj/ issue10aren22 \\
\hline URL: & https://doi.org/10.29370/siarj/ issue10aren22 \\
\hline License: & Copyright c 2017 NC-SA 4.0 \\
\hline Journal homepage & www.siarj.com \\
\hline Published online: & $2020-05-31$ \\
\hline
\end{tabular}
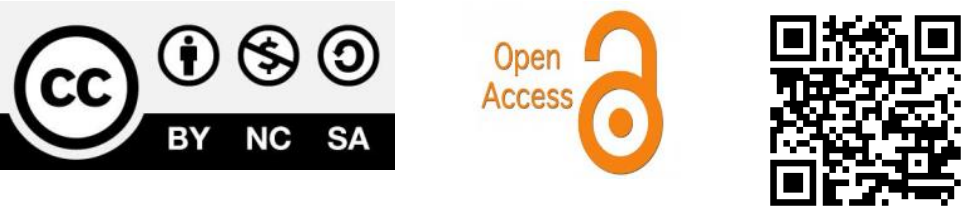
THE SCHOLAR (January- June 2020)

\title{
COVID-19: ITS IMPACTS AND MANAGEMENT IN THE ISLAMIC SOCIETY OF PAKISTAN
}

\author{
Sayeda Daud, Masroor Khanum, Fatima Agha Shah
}

\begin{abstract}
:
From the very beginning, this uncomfortable disease has killed more people than for any other reason. The pandemic of the end and the disease (COVID-19) has gradually shown how powerless we are. Muslims are the second tightest group on the planet, accounting for about a quarter of the total population. They have a remarkable sense of nobility and culture, given their strict practices and beliefs, which require exceptional attention in an environment such as the current COVID-19 pandemic. The network's petition is an integral part of Islamic culture. It is compulsory for every adult male Muslim to perform the necessary intercession in the community, who has no reason not to do so. In any case, such actions can help to spread COVID-19 during a pandemic. Muslims admire the Holy Quran and the teachings of the Prophet (PBUH) (Hadith) to lead in all circumstances. The purpose of this article is to discuss the nature and impact of the Pandemic: COVID-19 on the people of Pakistan in Islamic Perspective, which is also the scientific view proven and accepted globally today.
\end{abstract}

KEYWORDS: - Divine Punishment, Fatalities, Screen, Sunnat al Allah, Covid-19

\section{INTRODUCTION}

Covid- 19 is a kind of divine punishment. The place of origin or the causes of its birth matters least in the divine system. Under the current situation, it is impossible to predict how much causality will occur in a defined 
geographical area or in the whole world in aggregate. Physically, in the whole world, every individual cannot be screened despite the miraculous technological development that has taken place in the world; Covid-19 has affected all aspects of life. Schools, colleges, universities, playgrounds, marriage halls, amusement parks, festival grounds have been closed to avoid the spread of Covid-19. Even many International sports events have been postponed or cancelled due to the fear of this pandemic. According to a report in the daily Dawn national tally of Covid-19 was 227,254 and numbers of fatalities were 4680 as of July 5, 2020. (Daily Dawn, July 5, 2020)

Allah does not change His decisions or (Sunnat al-Allah) or His will (17: 77). No matter who the beneficiary or the victim is? He has no wife, no son and no relatives. He has set up some principles, pathways and rules, whosoever willingly acts according to His ways and desires will succeed. Allah's help, mercy and booty are divided among those whom He wishes. At this hour of trial and tribulation, the Islamic community or nation shows resilience and adaptability to behave normally by facing the challenge as one united community or ummah. Whenever a torment or calamity or disaster falls, it does not distinguish between the Muslims and non-Muslims, between rich and poor, between affluent people of the society and the downtrodden, and between the individual and community. The coronavirus pandemic has hit hard domestic staff and attendants. The calamity takes its toll even from the well-placed and affluent factions of the society along with the have-nots. The purpose of this article is to discuss the nature and impact of Pandemic-Corona-19 on the people of Pakistan in Islamic Perspective. We will endeavor to find out the answers to the following question It will be descriptive and analytical study to ascertain the facts and figures. 
In this article, we will endeavor to provide answers to some questions about the diseases from the Holy Quran and the latest findings of it:

1. How does Islam treat a catastrophe, pandemic, torment, and a virus?

2. What are the teachings of Islam in order to combat or fight this(any) pandemic?

3. What are the duties and obligations of an Islamic State in case it is faced with such calamity?

4. What has been the reaction of the ummah, and in particular, the Atba, Ulema and Muslim rulers to contain or eliminate this catastrophe, and finally what are the conclusions and suggestion for future.

The evidence for the article is taken from the Holy Quran and Hadis and for recent developments and progress from available literature and websites.

The news spread like wildfire about the outbreak of COVID-19 from the Chinese city Wuhan in December 2019. Now it has engulfed the whole world, yet a section of masses is not serious about it.

This segment of the population includes

\section{MUSLIM SOCIETY}

In order to solicit the response of question 1 and 2 , it is important to analyze and understand the nature of Muslim society and the duties and functions of Muslim individuals. Members of the society believe in the directives of Islam and the total obedience of the laws of Allah and the traditions of the Holy Prophet (PBUH) i.e. Sunnah. The attraction of these laws and messages lies in the simplicity, in its power, its universality, and rapid diffusion among the learned and the common man.

Islam is basically a code of life which is simple to adapt and easy to follow. It provides guidance for every walk of life with logic and simple to 
practice. The Holy Prophet's (Peace Be Upon Him) whole life was practical guidance of the Holy Book; so that no one can ever claim that the Belief is only bookish knowledge which cannot be carried out in real life. The instructions are there for all situations of life; be it laws of the society, business, morality, socials norms, laws of matrimonial guidance and laws for divorce, after divorce matters, custody of children and it's all aspects, heritage laws for all members of the family (including women) in the minutest details; rights of the parent, wife/s; all legal issues of a person as well as the society; about servants and slaves. It has every detail about the natural and social sciences. The Holy Book also reveals about all about natural sciences mankind has discovered till date and about those phenomena not yet comprehended or discovered by man despite the advancements he claims.

In the fields of medicine Muslim scientist of Islamic era most renowned and are the predecessors of the modern medical field of today; spreading into Europe through Muslim Spain along with other scientific, social and cultural knowledge of the Muslims. Tibb-e Nabawi (Medicine of The Holy Prophet) is a prominent branch of medicine even today.

Islam was the first religion to establish a well-fare state and announcing the charter of Human Rights by the Holy Prophet (SAW) Himself. The Islamic society since that time is a welfare society (state), aiming the wellbeing of a common man. In Hazrat Umar's (PBU) words: 'even if a dog dies of hunger in my reign, I am responsible'.

It is obvious that in time of spreading of contagious pandemics clear instructions and measures for prevention, treatment and cure were taken in the light of the teachings of the Holy Book and Hadiz (practices of the Prophet (SAW) in the light of Quran), which could never be negated even, by the enemies of Islam. 
As a Muslim completely surrenders to the will of Allah Almighty. He believes in the sovereignty of Allah over the entire universe. He preaches the virtues and forbids the evils. He is commanded by Allah and His Prophet to act piously and remain an obedient slave of Allah and trust only in Him as He is the Best Healer, as revealed in the Quran.

The Quran says $(2 ; 112)^{1}$

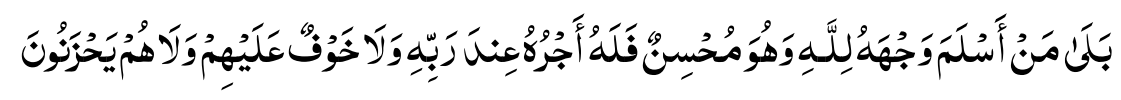

Nay, but whosoever surrendered his purpose to Allah while doing good, his reward is with his Lord; and there shall no fear come upon them neither shall they grieve.

In another place Allah says (4: 125)
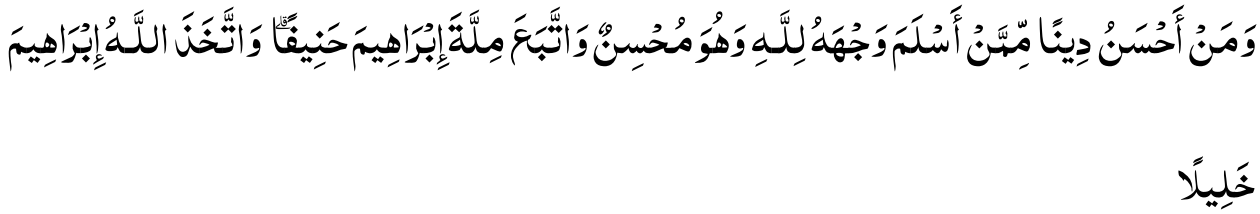

Who is preferred in religion to one who, when he performs great deeds, communicates his motives to Allah and observes the common belief in Abraham's sincerity? Allah (Himself) chose Abraham as a companion.

The believer claims that Allah is one. He is the one who gives, withholds, gives openly to whom He wills, without application. The believer cannot be a child. He is respectful, kind, steadfast and sincere, for these qualities underlie the firm trust he places in the matchless being who raised him and

\footnotetext{
${ }^{1}$ Holy Quran, Surah 17, Ayat 77
} 
Covid-19: Its Impacts and Management in the Islamic Society of Pakistan appointed him as His representative on earth (Khalifa). (Abdur Rahman Azzam P. 75) ${ }^{2}$

Muslims are bound to obey Allah and His Messenger individually and collectively in community and this obedience must be given priority to every other obedience. Consequently, obedience to any other person comes after it and not before it, and it is subject to it.

The renowned scholar of Islam whose piety and knowledge are acclaimed all over the world, Maulana Taqi Usmani says that Corona Virus is the consequence of our misdeeds. He expressed his views on Corona-19 as follows: -

"Corona-19, Dengue, locust, earthquake or sinister design of the enemy and our cowardice - are they not enough for our punishment ----He laments the misdeeds of our nation. Instead of showing repentances to our Lord Allah and supplicating to Him to ward off this torment. The miscreants of the society seized this opportunity for hoarding basic commodities and for profiteering and for soaring prices. Has the time not come for us to show repentance to our God -Allah and abandon our malpractices? ${ }^{3}$

In such a situation Islam teaches us a lesson. According to the Ayats of the Holy Quran, “cyclones, floods, earthquakes, viruses, windstorm, brim storm, sandstorm, deafening shouts, thundering clouds are different types of Allah's punishment. One should bear in mind that these punishments

2 Azzam, Abdul Rahman, "The Eternal Message of Muhammad." New York: David Adair Company, 1964 P. 75)

${ }^{3}$ Maulana Muhammad Taqi Usmani, A Tweet on Tweeter, $18^{\text {th }}$ June 2020 . 
Covid-19: Its Impacts and Management in the Islamic Society of Pakistan are inflicted on human beings as a reward of their deeds. This is what they deserve for their mischievous acts.

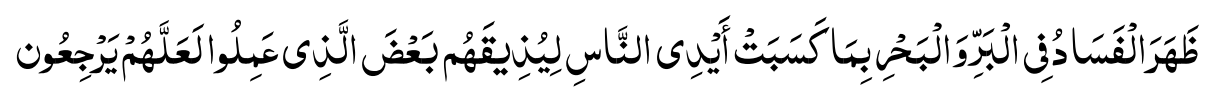

(Al Quran 30: 41) Corruption doth appear on land and sea because of (the evil) which men's hands have done, that He may make them taste a part of that which they have done, in order that they may return.

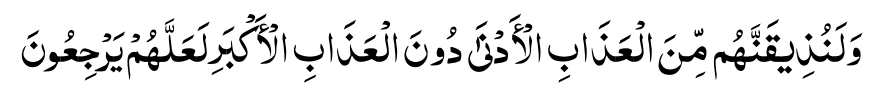

And verily We make them taste the lower punishment before greater, that haply they may return

Allah ordains that the believers should come back to Allah after Al Allah's punishment has been inflicted on them repenting about their sins so that Allah may forgive them

In another place, Allah says," We showed them signs after signs each greater than its fellow and we seized them with punishment, in order that they may turn to us."

Islamic teaching about viruses is clear and manifest. If sufficient precautionary measures had been taken by the people and the government, huge numbers of deaths could have been avoided. Maulana Abul Ala Maududi explained, “evil done by men's hands' means, disorder, disobedience, cruelty, illegal acts, torture and unjustified acts which is a natural phenomenon of shirk, godless society and disbelieve in the last day of judgment. They may return mean Allah showeth some punishment

\footnotetext{
${ }^{4}$ Holy Quran, Surah 30, Ayat 41
} 
Covid-19: Its Impacts and Management in the Islamic Society of Pakistan

inflicted on a human being in this world before the torment of Akhirah so that they may heed and realize their mistakes and sins.

\section{PRECAUTION: PROHIBITION OF MOVEMENT:}

In the year 18 A.H. a virus broke out in Syria which is called TAAUN AMWAS during the tenure of the second pious caliph Umar (Razi Allah Unho). He was on his way to Syria. On the way, he was informed at TABUK by Abu Obaidah bin Al-Jarrah and others about the outbreak of TAAUN AMWAS. Caliph Umar consulted the Muhajireen (Immigrants from Mecca to Madinah) and the ANSARS ( people at Madinah who help Muslims to settle in Madinah) about his journey. Most of them advised that he should go back to Medina. During the discussion Abdur Rahman Bin Auf ( Razi Allahu Unho) who was one of the respectable companions of the Holy Prophet ( Sahabi) narrated a Hadith ( tradition of the Holy Prophet) He said,

"THE HOLY PROPHET SAID WHEREVER THERE IS A VIRUS

AND YOU ARE THERE, DO NOT LEAVE THAT PLACE AND DO NOT ENTER A CITY WHERE THERE IS A VIRUS" 5

After hearing the hadith caliph Umar went back to Medina. This virus continued for months. Many notable companions of the Holy Prophet died by the infection of this virus. Among them are Abu Obaidah Bin AlJarrah, Muad Bin Jabal, Yazid Bin Abu Sufian, Harith Bin Hasham and Sohail Bin Amro. All of them were soldiers of Islam. All of the were stationed in Syria. Islamic State suffered the colossal loss.

According to Muslim historians, about twenty-five thousand Muslims were martyred. Muad Bin Jabal had appointed Amro Bin Aas as his

\footnotetext{
${ }^{5}$ Muslim I. Sahih Muslim, Volumes I-IV. Translated Muhammad Muhsin Khan. Al Saadawi Publications, 1996; Hadith 1369.
} 
Covid-19: Its Impacts and Management in the Islamic Society of Pakistan

successor. Addressing to the Muslim soldiers Amro said the virus spreads like wildfire, go all of you and seek shelter in the mountains. It was an order of social distancing and isolation. After some months, the virus subsided and then vanished. This example has been set for the Muslims and it was in consonance with the modern medical requirements i.e. social distance and isolation. ${ }^{6}$

In another Hadith narrated by Usama Bin Zaid ( Razi Allahu Unho), the Prophet said," IF YOU HEARD ABOUT PLAGUE IN CITY, DO NOT ENTER THAT CITY AND IF YOU HAPPEN TO BE IN THAT CITY, THEN DO NOT EXIT FROM THAT PLACE.

Therefore, restrictions imposed by the government on inter-city transport and travelling is legal in an Islamic state. Likewise, any restrictions imposed by the local authority to curb the free movement of the people in order to prevent the spread of the plague from one place to another is not only permissible but is required for good governance.

It is natural that if people from the city where the virus has inflicted thousands of the people, migrate or travel to other cities, they will carry with them the disease and its symptoms to the place they migrated. This is what happened in Sindh province in Pakistan. The people of Pakistan who had gone to Iran to visit their religious sites came back to Pakistan, inflicted with a virus because Iran was already a victim of Covid-19. According to media reports about nine thousand people have died in Iran. In another hadith, the Prophet is reported to have said, "No patient should visit or meet the healthy people." We have the authority of the Holy Prophet in regard to keeping a social distance from a person who was

\footnotetext{
${ }^{6}$ Ibn Majah. Sunan Ibn Majah. The Chapters on Business Transactions; Vol 3, Book 12, Hadith 2140.
} 
Covid-19: Its Impacts and Management in the Islamic Society of Pakistan

suffering from the pandemic, One person who was suffering from leprosy from the tribe of Bani Thaqif, wanted to come to the Holy Prophet for the oath of allegiance, When the Holy Prophet heard about him, the Prophet conveyed the message that he should go back and need not come. The Prophet accepted his oath in absentia.

It was according to the instruction of the Holy Prophet, that Muslim rulers of the medieval ere had built separate hospitals for the patients suffering from the pandemic. The Prophet used to adopt the precautionary measure and used to advise others as well. It is very well known to Muslims that Prophet used to advise the Arab villagers to tie the knot of the legs of camel or horse before they sleep or go for basic needs. This was in the spirit of Tawakkal.

Summarizing briefly, it can be said without any doubt that the pre-cautions and social distancing and isolation of the patients which are being preached nowadays and which are being disseminated through print and electronic media are legacies of the Muslim rulers, states and the traditions of the Holy Prophet.

Purity and cleanliness, washing human bodies, covering nose and mouth when sneezing with hands or clothes, washing hands multiple times with soap, keeping a distance of at least one meter from the visitor, avoid meeting with the Corona infected people, quarantining oneself or other impacted persons, living in isolations to avoid exposure of the virus, are all Islamic teachings which the modern scientists and health officers or WHO have adopted. Humanity can benefit by adopting them, enforcing them, legalizing them and compelling people to accept them as normal practice 
in their lives.

According to Islamic belief, death is imminent. Everybody must die; everything in this world must perish. The Holy Quran says

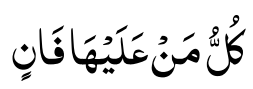

All that is on earth will perish

In another place the Holy Quran says 4:78

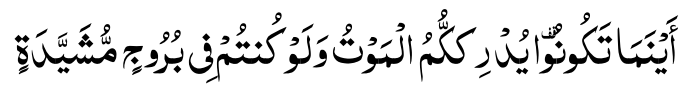

Wherever you may be, death will overtake you, even if you should be within towers of lofty construction. But if good comes to them, they say, "This is from Allah "; and if evil befalls them, they say, "This is from you." Say, "All [things] are from Allah." So, what is [the matter] with those people that they can hardly understand any statement?

If Allah wills, people will die even if they had adopted all precaution. Death will overtake them even if they live in lofty towers.

Therefore, the plague and death are pre-ordained by Allah

\section{NATURE AND CAUSES OF COVID-19:}

According to an Islamic belief system, The Covid-19 is not made in China nor made in Europe. It is ordained by Allah's will. Allah does not wish that his creature has perished. We do not know but Allah definitely knows when the world will perish and perish it shall. We have discussed above that whatever calamity is befallen on us; it is because of our wrongdoing. However, this world is the world of cause and effect. Then we must find

7 Maher, A. (2006). General rules for dealing with crises (crisis management). Alexandria, Egypt: Alexandria University House 
out what are the causes of this catastrophe. Believers possess a brave heart. They have the courage to express their views. They do not fear death because only Allah can cause it. Their souls are exalted. In order to defend the truth and to protect themselves in bondage to Allah against tyranny and disdain, they can go forward even to martyrdom, if necessary.

Certainly, Corona-19 is the latest of all diseases known to mankind. The human being did not know of it before. Had they known it, the scientists and the medical doctors would have invented drugs, injections and preventive medicines. Nobody knew it until thousands of people in Asia and Europe died. Surely this was one of the many catastrophes that Allah hath stored to punish mankind for their misdeeds.

\section{CONSEQUENCES:}

The masses are suffering from hunger and poverty as a result of lockdown. To remedy the situation, the spirit of the philanthropist is noteworthy. People in Muslim society distribute food and alms to the needy and the poor. Ration package is being prepared and distributed to the masses. These are praiseworthy efforts. However, one must not forget those who do not beg because they are ashamed of begging, yet they are needy. They can starve but they do not ask for monetary help from others.

The Holy Quran has described these qualities of the Momin at two places (70: 24,25$)^{8}$

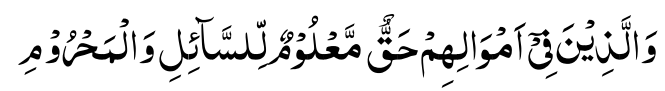

One needs to know the explanation of these verses. It means the believes whenever they offer charity, they do not think that they are bestowing

\footnotetext{
${ }^{8}$ Mawlana Abdul Hafiz bin Abdur Rauf, Subject based verses from Quran and Hadith, Islami tower, Banglabazar, Dhaka, 2011.
} 
favor to the payee. They realize that the amount they are offering is the right of the payee because Allah has allocated it.

We know that in our society there are people, our friends, relatives, colleagues, daily wages labors, who are needy but they do not beg rather abhor begging, then it is the duty of the Muslims society to come forward and offer financial assistance without hurting their integrity and ego.

The fact is known to everyone that during this Pandemic a good number of people are distributing food, alms, charity, clothes and other basic necessary items for livelihood to the masses without any distinction of race, color, religion and ethnicity. Such people are those who will be under the shadow of Allah's throne on the day hereafter. This is according to the Hadith of the Holy Prophet (SAW).

In a long Hadith of the Holy Prophet narrated by Muslim 2569, the Prophet (SAW) emphasized that service to humanity has been assigned the highest degree of obedience in the sight of Allah

Likewise, those who are serving human beings for their health and betterment during this Pandemic are placed on the height whom Allah is pleased with, they may rightly be called MUJAHIDEEN OR JIHADIST (striving in the cause of Allah). Unfortunately, those who have lost their lives in the service of humanity during this Pandemic are undoubtedly called SHAHEED

According to Islamic teaching, dead bodies are respected. They should be honorably buried sooner than later. Islam does not allow mutation of dead bodies. In Islam, the dead are buried with all religious rites and the Muslims pray for the atonement of the dead. No virus, no symptom of disease or plague remains alive in dead bodies. This what the World Health Organization has confirmed.

\section{ROLE OF WHO FOR PREVENTION OF THE COVID-19:}


While talking to BBC's program 'Hard Talk', on 18th November 2020, special envoy of WHO Covid-19, David Nabarro, showed concerns about the lack of capability of the World Health Organization that despite lock down the number of cases did not come down.

As there is no vaccine available yet, and infected cases are rising alarmingly again as the second wave in those countries who suffered badly earlier and are still in a grave situation. The economy is also suffering due to job losses and economic activities around the globe.

Amazingly, Mr Nabarro gave the example of poor nations of Asia who copes with this condition successfully, without any modern facilities which the rich nations enjoy.

He mentioned that 65 staff members are also infected with corona also and admitted that there is no way to corona from spreading.

Only preventive measures can control it from becoming the worst catastrophe than before.

The safety measures will now become a norm of life.

He admitted that Herd immunity is a blessing in this situation.

Vaccination is still far away because the masses will get it late next year in the west. For poor nations, affordability will be a big question mark.

The transportation of vaccine is also difficult due to the maintenance of a certain temperature to preserve it. The acquisition of the vaccine is feared to be politicized. These are the views of an official of the health organization!

This is the evidence that despite all resources of the world man is helpless before will of Allah Almighty.

Who is responsible for this situation, if it is a man-made crisis? Was this virus cultivated in any laboratory on purpose to harm humanity? Like nuclear weapons and poisonous gases? 
Are such inventions blessing of God or curse for humanity?

Are people with this mindset not to be punished for the crime against humanity?

The Holy Quran stated clearly that; if such crimes become a norm of society the Allah Almighty will send His justice for their punishment. ${ }^{9}$

\section{ISLAMIC STATE}

We now turn our attention to question number 3 and ascertain the duties and obligations of an Islamic State.

As Islam is an all-inclusive religion with its legitimate belief system and standards identifying with creed, law ethics, goals, rights, and commitments. It isn't limited by area, race, identity or shading. Along these lines, Islam's idea of sway lies in the Shariah. All in all, it lies in those interminable standards of Islam on which its main goal has been predicated. Thusly, it isn't the privilege of a country - overall or partially whether in concurrence with the top of the state or not, if spoken to by the constituent get together to temper with this endless character of rights and obligations appointed by Allah for all humankind, separately and on the whole in a specific land all through mankind on the loose. These standards are sovereign and unceasing in light of the fact that it is simply by the desire of Allah that their progression is kept up. This is an incredible and principal Islamic idea. (Abdul Rahman, P.119)

States have sovereignty over all matters but must conduct themselves within the limits prescribed by Allah through His revealed book and the Sunnah (words and actions of the Holy Prophet). His words are supreme.

\footnotetext{
${ }^{9}$ UNICEF: Cleanliness in Islam, link- https://www.unicef.org
} 
Shaikh Muhammad Khadhiri a contemporary Egyptian author on Islamic Jurisprudence says in his book Usul al-Fiqh:

Since the command is the right of Allah to decide, none of them has the right to give any command whatsoever. All Muslims agree on this point. It should be noted that Islam endows all Muslim inhabitants of an Islamic state with a viceroy. Consequently, this viceroy is known and not limited to any person, class or group. It forms the premise of a popular government.. As it turns out, the power belongs to the Muslim people of the state as a whole, not to any person or assembly. (Maududi, P.258) ${ }^{10}$

\section{POWERS AND FUNCTIONS OF AN ISLAMIC STATE}

The Quran states that $(22: 41)$
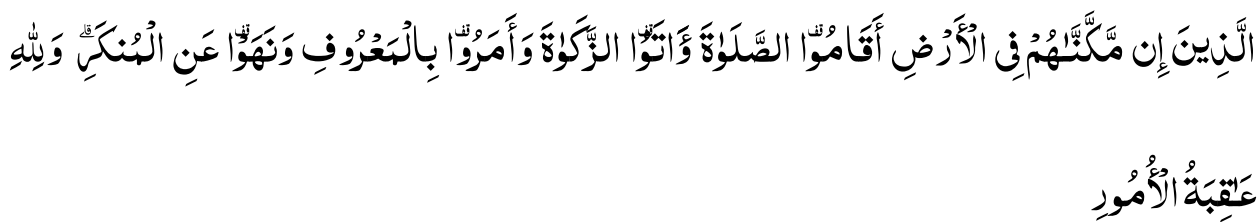

Muslims are people who, not knowing that We will give them dominion on earth, establish the order of salat (love) and zakat (poverty) and enjoin perfection and forbid obscenity, and all affairs rest with Allah (22:41). That is, Allah has a place for everything that matters.

This stanza obviously refers to the Islamic State's points, goals and obligations. Unlike the mainstream, its obligation is not simply to keep everything under control, guard the edges and work for the material prosperity of the nation. Or perhaps, above all, its duty is to establish the device of salat and zakat, to spread and establish what is considered ethical

${ }^{10}$ Cited by Maulana Maududi, The Islamic law and Constitution, Lahore: Islamic Publication, $7^{\text {th }}$ ed., 1980, P. 263.) 
by Allah and His Messenger, and to kill what has been declared by them to be bad habits. In general, no state can be called Islamic unless it fulfils this essential purpose of an Islamic state. It follows that a state which is not concerned with establishing ethics and killing obscenity, and in which infidelity, drunkenness, betting, abominable writings, obscene films, obscene melodies, corrupt display of perfection, senseless mixing of people, rioting together and so on flourish without permission and hindrance, cannot be called an Islamic state.

Allah has inflicted punishment, torment, retribution on the people who transgressed his boundaries and, on the rulers, who crossed all the limits imposed by Allah. Allah has punished rulers whenever they transgressed His limits or whenever they become tyrants, or they become unjust to the masses. No better example can be produced than that of Pharaoh (FIROUN) who was drowned in the water after the downtrodden people of Bani Israel had crossed the river.

Another example can be produced of the King NIMRUD who was the ruler at the time of Prophet Ibrahim (PBU). He met with his death in a shameful manner.

And Allah sent down the flights of birds (ababeel) with a stone of backed clay in their claws to hit the companions of the elephant (Chapter 105). Allah did this to save His house of Worship (Kaaba).

In cases where Allah has destroyed the whole nation, it was the fault of the people of that nation that was responsible for retribution. When the whole nation becomes corrupt, cruel, dacoit, plunderer, profiteer, and terrorist, unjust and irresponsible, then Allah destroys them all. Let us study one by one. The people of Aad were a superpower. They were self- 
sufficient in all commodities. Allah punished them by cutting their roots. (Holy Quran; 7: 72) ${ }^{11}$

The people of Thamud disobeyed Allah's command openly and blatantly. They were affluent people and arrogant. They hamstrung the camel which was produced miraculously by the Prophet of Allah Saleh (SAW) So Allah punished them. "So, the earthquake took them unaware and they lay prostrate in their homes Holy Quran; 7: 78).

The people of Shoaib (A S) were crocked, dacoits and usurped the commodities on the pathways. The Prophet of Allah i.e. Shoaib warned them and beseeched them not to commit mischief. But they remain adamant. IT was the nation of Shoaib who was ruined, (Holy Quran: $7: 92)^{12}$

\section{PAKISTAN AS AN ISLAMIC SOCIETY:}

The All India Muslim League, the ideological group that led to the creation of another country for Muslims in British India, overlooks all the topographical and socio-social contrasts among Muslims. It all depended on religion as an adequate motivation for the creation of another country. Incidentally, most of the pioneers of the Muslim League, including President Mohammad Ali Jinnah, were liberal. Again, the Muslim strict pioneers were against Pakistani development. Nevertheless, "They probably changed their views after the segment." - Pakistani writer Ahmed Rashid notes in his book, Descent into Chaos. Soon after Pakistan's creation, those who disagreed with the strict assembly began to call for the

\footnotetext{
${ }^{11}$ Holy Quran, Surah 7, Ayat 72

12 Dr. Saleem Khan, "Corona-19 The Trial of the wealthy People," Tarjumanul Quran, June 2020, P.96.)
} 
Islamization of the nation and the eventual inclusion of Islamic rights in the constitution. Thus began the struggle between nonconformists and Islamists. The Jamaat-e-Islami (JI) strict assembly and its creator, Maulana Syed Abul-Ala Mawdudi, took considerable work and left their stain on the nation's governance affairs. Today's Pakistan has deep roots of Islam in its society as well as of other aspects of individual and collective matters. The constitution declares the country as the Islamic Republic of Pakistan and any practice that goes against the Holy Quran and Sunnah can be nullified by the Supreme Court of the country. Religion is taken seriously by the state and the people alike, issues like cartoons of Prophet Muhammad and the Ahmediyaa issue have been dealt with rigorously by the country. ${ }^{13}$

\section{EFFECTS OF COVID-19 ON PAKISTAN:}

As in many other countries, early failures dominated the Pakistani government's response. In Feb-ruary, state authorities could not send many Pakistani students back to Wuhan, China, because of a paranoid fear of contagion. This decision seems reasonable in and of itself, despite the fact that state authorities could have sent them home no matter how isolated they were. Be that as it may, despite the cautious treatment of Wuhan residents, it failed to screen sufficiently close to the re-searchers, many of whom were carriers of the infection. The first confirmed case of COWID19 in Pakistan occurred when an understudy from Karachi returned from a trip to Iran on February 26. Shiite travelers returning home from Iran, then the most influential country in the region, made up the bulk of the

\footnotetext{
${ }^{13}$ Islam and Politics in Pakistan. (2020). Retrieved 27 December 2020, from https://www.cfr.org/backgrounder/islam-and-politics-pakistan
} 
imported infected. State authorities isolated many travelers in absurd, unsanitary conditions near the border with Iran and then allowed them to travel to their hometowns without proper testing or segregation, spreading the infection throughout the country. A general health emergency and a monetary lull can have shocking effects, especially if people feel they are being taken seriously. Resentment against state power and social pressure are intensified when people feel that state power could not care less about their welfare and prosperity. Aggressor gangs used these cases to support their neighbors.

While COVID-19 leaves some decent prospects for the Pakistani government, some phases may cause less than expected damage to lives and occupations. The prime minister's interest in the aftermath of the barricade is legitimate. Considering all these factors, it is impossible for the economy to develop if the specialists can't keep an eye on the infection. A change in clever prevention methodology can escape the torment of wide-area barricades while saving lives. It could mean that regions will be able to shut down entire cities and towns for short periods of time when specialists want to, instead of being confined to incomplete runs. By and large, government agencies should lead the way here, but leave areas where approaches adapted to the needs of neighbors can be created. The primary goal should continue to be strengthening capitation for area health care, particularly in the area of research. Crisis assistance for families hanging on the "poverty line" and for the unemployed remains fundamental. Prime Minister Imran Khan's interests - and the nation's would also be best served by engaging in this process while resisting fabricating an agreement on the results of a phenomenal and potentially 
The Scholar Islamic Academic Research Journal

Vol. 6, No. 1 || January-June 2020 || P. 353-378

https://doi.org/10.29370/siarj/issue10aren22

destabilizing welfare emergency. ${ }^{14}$

\section{PAKISTAN SUFFERS THE CONSEQUENCES:}

Daily wages workers are fired, housemates are fired, guards are fired, nurses who are hired to take physical care of old persons, physically handicaps are fired mainly due to lock-down. The present Federal Government of Pakistan has distributed around Rs. 150 billion among the 15 million poor and deserving people of the country. This is a laudable step and it must be appreciated. Hundreds and thousands of people had lost their job or livelihood because of the lockdown or retrenchment process of the industries, markets, mall, manufacturing industry, transport and tourism.

Whenever a torment or calamity or disaster falls, it does not distinguish between the Muslims and non-Muslims, between rich and poor, between affluent people of the society and the downtrodden, and between the individual and community. The coronavirus pandemic has hit hard domestic staff and attendants. The calamity takes its toll even from the well-connected and organized families.

One of the duties of the Islamic state is to provide welfare facilities, feed the poor, the needy, the destitute, the widows, the orphans as much as possible and as far as possible. Therefore, a policy of the Federal Government to distribute cash to the deserving people during the period of Corona Virus is indeed a policy in the right direction,

\section{4}

Pakistan's COVID-19 Crisis. (2020). Retrieved 27 December 2020, from https://www.crisisgroup.org/asia/south-asia/pakistan/b162-pakistans-covid19-crisis 
Most industries are closed or working on minimum staff. Therefore, low paid staff and daily wages earners are fired, or their contracts are not renewed. For household work, reliable and trustworthy people are hard to find. The question is how the fired workers will find a job amidst the pandemic. The breadwinner of the families is laid off, leaving wife, children starving and wondering how to live.

According to Pakistani newspapers reports, the most vulnerable age group to the disease is people aged between 60 and 69, The second most vulnerable age group is 70 and 79 years old. People between the age of 50 and 59 are the third most vulnerable

Social and economic changes have surfaced in Pakistan. It is evident that Corona has brought major changes in normal living standard and business. The US government has donated 100 ventilators I support of Pakistan to fight against Covid-19. The ventilators are valued at about $\$ 3$ million

\section{CONCLUSION AND RECOMMENDATIONS:}

Now we will address our question number 4 to elaborate the Islamic method of treatment of plague or virus by medicine, dispersion, social distancing and isolation for treating the plague or virus. Amr Bin Aas has set a golden example at the time of famous plague which appeared in Syria during the reign of the second caliph.

People should avoid shaking hands with each other particularly during the period of the plague. Extra care should be taken when visiting each other and certainly, there should be no shaking hand with the patient of the plague. Holy Prophet had set the example of not shaking hand and personally meeting with a patient of leprosy.

No free movement of the people is allowed either inside the city or from other cities. It is necessary to avoid gathering or general meeting of 
the masses to prevent the spread of the virus. The famous hadith of the Holy Prophet in this respect is a command for the general Muslims.

Medical test of the suspected patients is conducted frequently in order to ascertain the presence or non-presence of the virus. If a virus was found, the patient should undergo treatment and be kept aloof from others.

It may happen that ostensibly symptoms may not appear, yet the test may be positive as it happened in the case of the Speaker of Khaybar Pakhtoon Khaw Assembly, then it is better to be in isolation for fifteen days at least as recommended in Tibb-e Nabwi and as per latest medical research.

The Muslims pray five times a day thus are already following the measures of hygiene, whereas the latest health advice is to wash hands frequently, to disinfect hands.

The annual pilgrimage or Hajj is the time when Muslims from all over the world gather to gather to perform certain rituals. For the health, betterment, long life of Muslims, for the preservation and protection of human lives, it may be recommended that the number of pilgrims may be drastically reduced.

It is the general practice in the affected states of the world that the governments there imposed complete lockdown. No business is allowed. No movement outside the houses is allowed. No gathering is allowed. Parks are closed. Schools and colleges are closed. Mosques are closed. Markets are closed. It is difficult for a human being to survive in such a situation.

For the comfort of the people, for their survival and to make provisions for the poor people to earn a daily livelihood, it is better to impose what the Prime Minister of Pakistan Imran Khan calls, "SMART LOCKDOWN". 
The writer acknowledges the shining example of IJMA (Consensus of the Ummah i.e. Learned Scholars) exhibited by the Ulema of the Muslim world at this time of universal plague

The Holy Prophet (SAW) is reported to have said, "There is no disease on earth that Allah has not produced a cure for it." THEREFORE, Muslims must undergo medical treatment.

If we want to awaken the Muslims, in order to protect their lives from the onslaught of this Pandemic, it is the duty of the learned scholars of Islam in the present time to keep the Ummah informed about Quranic injunctions. The Islamic principles, if any, which were adduced or enacted in the past during the zenith of Islamic civilization, were not enough.

Authorities in Pakistan must take steps to prevent the resurgence of the disease, particularly Eid Ul Adha. Fortunately, Our Prime Minister is not only well aware of the dire consequence the Pandemic may bring if the proper preventive measure were not taken by the Government ministries and other agencies, but he is very active in directing various government ministries and agencies to tighten their girds and take appropriate steps so that casualties from the Covid-19 could be minimized and curtailed. The Government has to check how the casualties may be prevented from the smart lockdown. According to reports of IMF and World Economic Outlook, Pakistan is among the group of thirty countries that reversed the projected downturn from -0.4 to 1.0. (Dawn, Sunday, July 5, 2020)

The Punjab Government has issued new guidelines for the establishment and management for cattle market in the wake of COVID- 19 as well as prevention of the Crimean Congo hemorrhagic fever (CCHF) fearing its spread from sacrificial animals. According to the guidelines, the Government declared that the cattle markets should be established at designated points at least two to five kilometers away from the city. The 
management must ensure the controlled cattle entry. The parking areas should be marked for distance parking. Only two people will be allowed per vehicle.

It is a very astonishing fact that rich nations, in particular, are the targets of this pandemic e.g. USA, GERMANY, GREAT BRITAIN. SPAIN, ITALY, BRAZIL, and IRAN. On the other hand, most of the poor nations have been cured by herd immunity. Allah warns people," are they not afraid of the planning of Allah. No one can feel secure against the plan of Allah except those doomed to ruin. Why are they in loss or why are they suffering because they obey their selfish desires, they care less for their future, they disobey their lord and they ignore His commands.

Human history is replete with such examples, but people do not learn lessons. In the words of Quran: When Allah set seals on their heart, "they see not, and they listen not".

In Islamic teachings, there is a well-known dictum that when a man starts illegal and unethical use of natural resources, then starts the destruction of natural amenities.

The current pandemic has posed a great challenge to the learned Muslim scholars, whether they can meet the task of codifying Shariah Laws, in the light of the Quranic injunctions?

In this world, a new generation is born after a certain period. According to Islamic teaching, the world is an examination hall, where the whole generation is being tested about its deeds. The good-doers will be rewarded, and evildoers will be punished. Every generation of human being has been tested and will continue to be tested. For each generation, the test papers are different. New torment, mew calamity, and new kind of punishment are inflicted on the human being in order to ascertain who is thankful to his Lord and who disobeys his lord. 
The Scholar Islamic Academic Research Journal

Vol. 6, No. 1 || January-June 2020 || P. 353-378

https://doi.org/10.29370/siarj/issue10aren22

To conclude the discussion, we must pray as a Muslim to Almighty to save us, to protect us from this calamity. If this pandemic is punishment, we should pray for the protection of the entire Muslim Ummah. COVID 19 is hitting way too close to everyone's home with a sad heart but with a strong faith in Allah SWT and pledge that all measures of prevention will be followed to contain this disease and support those who are suffering in every way possible.

\section{(ब) (1)}

BY NC SA This work is licensed under a Creative Commons

Attribution-NonCommercial-ShareAlike 4.0 International (CC BY-NC-SA 4.0) 